\title{
SIGNS OF PRODUCTIVITY OF YOUNG PIGS OF LARGE WHITE BREED AND THEIR RELATIONSHIP WITH UREA CONTENT AND ACTIVITY OF SOME BLOOD SERUM ENZYMES
}

\author{
Khalak Victor Ivanovich \\ candidate of agricultural sciences, senior researcher \\ SI Institute of grain crops NAAS of Ukraine \\ ORCID: 0000-0002-4384-6394 \\ Email: v16kh91@gmail.com
}

The results of studies of fattening and meat qualities of young pigs of large white breed, some biochemical parameters of blood serum (urea content, aspartate aminotransferase (AsAT) activity, alanine aminotransferase (AIAT) activity are presented), as well as the economic efficiency of research results is calculated. The study was conducted in LLC "Druzhba-Kaznacheyivka"of Dnipropetrovsk region, in the Research center of biosafety and ecological control of agricultural resources of Dnipropetrovsk state agrarian and economic university, meat processing plant «Jazz» and Laborator Livestock y of the State institution Institute of grain crops of NAAS of Ukraine. The work was performed according to the research program of NAAS of Ukraine №30 "Innovative technologies of breeding, industrial and organic production of pig products" ("Pig breeding"), state registration number 0116 U001247. The object of the study was young pigs of large white breed. Evaluation of animals for fattening and meat qualities was carried out taking into account the following indicators: average daily live weight gain during the control period of fattening, $g$, age of live weight $100 \mathrm{~kg}$, days, fat thickness at the level of 6-7 thoracic vertebrae, $\mathrm{mm}$, length of chilled carcass, $\mathrm{cm}$, the length of the bacon half of the cooled half-carcass, cm (M.D. Berezovsky, I.V. Kha'tko, 2005). A comprehensive assessment of young pigs for fattening and meat qualities was calculated according to the B. Tailer index (P.A. Vashchenko, 2019), biometric indicators - according to the methods of G.F. Lakin (1990). Economic efficiency of research results was calculated according to the generally accepted technique (Methodology for determining the economic ...., 1983). It was found that the urea content, activity of aspartate aminotransferase (AsAT) and alanine aminotransferase (AIAT) in the serum of young pigs of the experimental group corresponds to the physiological norm of clinically healthy animals and amount to $4.77 \pm 0.576$ mol/l, $68.11 \pm 6.445$ units/l, and $4.22 \pm 3.209$ units/l, respectively. According to the age of reaching a live weight of $100 \mathrm{~kg}$ (days), the thickness of the fat at the level of 6-7 thoracic vertebrae $(\mathrm{mm})$ and the length of the chilled carcass $(\mathrm{cm})$ of the specified production group and breed correspond to class I and class "elite". The maximum values of "average daily gain of live weight during the period of control fattening, $\mathrm{kg}$ ", "length of chilled carcass, $\mathrm{cm}$ ", "length of bacon half of chilled carcass, $\mathrm{cm}$ " and minimum values of "age of live weight $100 \mathrm{~kg}$, days" and "fat thickness per levels of 6-7 thoracic vertebrae, $\mathrm{mm}$ "are characterized by animals in which the complex index of fattening and meat qualities (B. Tailer's index) ranges from 157.68 to 182.36 points. The number of reliable relationships between the biochemical parameters of blood serum, fattening and meat qualities of young white pigs is $26.67 \%$. The cost of additional products obtained from young pigs with B. Tailer index of 157.68 - 182.36 points is equal to $+1732.04 \mathrm{UAH} /$ head.

Key words: young pigs, serum biochemical parameters, fattening and meat qualities, complex assessment, index, variability, correlation, economic efficiency

DOI: https://doi.org/10.32845/bsnau.Ivst.2021.2.6

In order to accelerate breeding work in animal husbandry, traditional and innovative methods of assessing breeding value and selection of highly productive animals are used, namely: by their own productivity, reproductive qualities of sows and breeding boars, fattening and meat qualities of their offspring, selection and evaluation methods, as well as DNA markers.

Thus, the results of studies Oliynichenko E.K. [1] indicate the influence of the marker CTSFg. $22 \mathrm{G}>\mathrm{C}$ on the intensity of growth and development of young pigs. The author found that animals of the GG genotype reach a live weight of $100 \mathrm{~kg}$ on 6.4 and 4.9 days earlier than analogues of the GC and SS genotypes, respectively. It is proved that the single nucleotide polymorphism of the leptin gene LEP g. $2845 \mathrm{~A}>\mathrm{T}$ affects the moisture holding capacity of meat and moisture content in the fat of pigs of large white breed of Ukrainian selection. The meat of animals of the AA genotype had a 5.6 and $7.6 \%$ higher moisture holding capacity compared to the meat of animals of the AT and TT genotypes, respectively. The fat of animals of the AA genotype had a lower moisture content by $6.8 \%$ and $19.2 \%$ compared to the AT and TT genotypes, respectively. It was found that SNP CTSFg. $22 \mathrm{C}>\mathrm{G}$ is associated with indicators of moisture retention, calcium content, energy value and melting point of lard.

An important addition to this is the search for biological markers of quantitative traits of animals of different sexes, namely interior indicators.

According to the results research of Krasnoshchok 0.0. it was proved that three-breed and hybrid young animals had an increased level of protein metabolism in comparison with purebred animals. Pigs of the combination of large white $\times$ (Duroc $\times$ Hampshire) predominated purebred pigs in terms of total protein by $35.58 \%$, albumin $-34.53 \%$, urea $-62.25 \%$, urea nitrogen $61.84 \%$; the predominance of hybrids was established by the content of total protein - by $28.21 \%$, by the content of globulins - $39.96 \%$, urea and urea nitrogen - 55.64 and $55.71 \%$, the activity of AsAT $-37.71 \%$.

The author notes that the use of Landrace breeders and terminal boars improves the meat qualities of domestic and hybrid pigs, namely: slaughter yield increases by $1.6-3.2 \%$, the area of the "muscle cell" $-7.2-13.9 \mathrm{~cm}^{2}$, ham weight -0.7 $-0.8 \mathrm{~kg}$, the thickness of the lard decreases by $6.8-7.8 \mathrm{~mm}$ [2].

According to Bazhov G.M. and others $[3,4]$ found high correlations between the content of total protein in the serum and the age of reaching a live weight of $100 \mathrm{~kg}(\mathrm{r}=-0.41--0.62)$, the average daily increase in live weight $(r=+0.41-+0.70)$ and 
feed costs per $1 \mathrm{~kg}$ of gain $(r=-0.55-+0.65)$. The obtained data show that the increase in growth energy is largely due to the high level of protein metabolism. The authors note that the data obtained have some contradictions, taking into account the relationship of protein metabolism with the productivity of pigs of different genotypes. It was found that in young pigs of steppe type (ST) meat breed SM-1 the level of total serum protein is positively correlated with the age of reaching live weight of 100 $\mathrm{kg}(\mathrm{r}=+0.34-+0.39)$, feed costs per $1 \mathrm{~kg}$ of growth $(r=+0.36-$ $+0.44)$ and negative - with the average daily increase in live weight $r=-0.41--0.50$ ).

The urgency and practical significance of the study of the interior of farm animals and the nature of the inheritance of quantitative traits are evidenced by the works of Siratsky J.Z., Fedorovich E.I., Hopka B.M., Fedorovich V.S. and others. [5], Lazareva V.M. [6], Likhach V.Ya. [7], Negreev A., Babushkin V. [8], Khalak V.I. [9], Khalak V.I. et al., [10, 11]. Furata S. Hashimoto T. [12].

The aim of the study was to investigate the fattening and meat qualities of young white pigs, some serum biochemical parameters, urea content, aspartate aminotransferase (AsAT) activity, alanine aminotransferase (AIAT) activity, and to calculate the level of correlations between traits and economic efficiency. research results.

Materials and methods of research. The study was conducted in the breeding breeder for large white pigs LLT "Druzhba - Kaznacheyivka" Dnipropetrovsk region, in the Research center for biosafety and environmental control of agricultural resources Dnipro state agrarian economic university, meat factory "Jazz" and livestock laboratory Institute of grain crops of NAAS of Ukraine. The work was performed according to the research program of NAAS of Ukraine №30 "Innovative technologies of breeding, industrial and organic production of pig products" ("Pig breeding"), state registration number 0116 U001247.

The object of the study was young pigs of large white breed. Evaluation of animals for fattening and meat qualities was carried out taking into account the following indicators: average daily gain of live weight during the period of control fattening, g; age of live weight $100 \mathrm{~kg}$, days; fat thickness at the level of 6-7 thoracic vertebrae, mm; length of chilled carcass, $\mathrm{cm}$; length of bacon half of chilled half-carcass, $\mathrm{cm}$ [13].

Comprehensive assessment of young pigs for fattening and meat qualities was calculated by the formula:

$$
I v=100+(242 \times K)-(4.13 \times L)
$$

where: Iv - complex index of fattening and meat qualities (B. Tailer index), score; $\mathrm{K}$ - average daily live weight gain, $\mathrm{kg} ; \mathrm{L}$ - fat thickness at the level of 6-7 thoracic vertebrae, $\mathrm{mm} ; 4.13$ constant coefficients [14].

Serum biochemical parameters in 5-month-old animals, urea content, aspartate aminotransferase (AsAT) activity, alanine aminotransferase (AIAT) activity were studied according to the generally accepted method [15]. by the formula:

The economic efficiency of the research was calculated

$$
E=Ц \times \frac{C \times \Pi}{100} \times Л \times K,
$$

where: E - cost of additional products, UAH; Ц - purchase price per unit of output, according to existing prices in force in Ukraine; $C$ - average productivity of animals; $P$ - the average margin of the main product (\%), which is expressed as a percentage per 1 head when applying a new and improved selection achievement compared to the productivity of animals of basic use; $\Omega$ - constant coefficient of reduction of the result, which is associated with additional costs for profitable products (0.75); $\mathrm{K}$ - the number of farm animals of new or improved breeding achievement, heads [16]. Conditions for feeding and keeping young pigs met zootechnical standards.

The pairwise correlation coefficient ( $r$ ) between the characteristics of performance and biochemical parameters of blood serum, the error of the pairwise correlation coefficient $(\mathrm{Sr})$ and the criterion of reliability of the pairwise correlation coefficient (tr) were calculated by the formulas:

$$
\begin{gathered}
r=\frac{\sum x y-\frac{\sum x \cdot \sum y}{n}}{\sqrt{C_{x} \cdot C_{y}}}, \\
\mathrm{~S}_{\mathrm{r}}=\sqrt{\frac{1-r^{2}}{n-2}}, \\
\mathrm{t}_{\mathrm{r}}=\frac{r}{S_{r}},
\end{gathered}
$$

The strength of the correlation between traits was assessed on the Chaddock scale (quoted by A.V. Sidorov et al. [17]) (Table 1).

Table 1

Chaddock scale for grading the strength of the correlation

\begin{tabular}{|l|c|}
\hline The value of the correlation coefficient & Correlation strength \\
\hline $0.1-0.3$ & weak \\
\hline $0.3-0.5$ & moderate \\
\hline $0,5-0.7$ & noticeable \\
\hline $0.7-0.9$ & high \\
\hline $0.9-0.99$ & very high \\
\hline
\end{tabular}

Biometric processing of the obtained research results was carried out according to the method of G.F. Lakin [18].

Results of the research. Laboratory studies of serum of young pigs showed that the urea content is $4.77 \pm 0.576$ $\mathrm{mmol} / \mathrm{l}(\mathrm{Cv}=34.13 \%)$, the activity of aspartate aminotransferase (AsAT) - 68.11 $\pm 6.445 \mathrm{u} / \mathrm{l}(\mathrm{Cv}=2.98 \%$ ), alanine aminotransferase (AIAT) activity - 44.22 $\pm 3.209 \mathrm{u} / \mathrm{l}(\mathrm{Cv}=21.77 \%)$. These biochemical parameters of blood serum correspond to the physiological norm of clinically healthy animals of this species.

It has been established that the animals of the controlled herd are characterized by rather high indicators of fattening and meat qualities. Thus, the average daily increase in live weight of nimals during the control fattening period is $788.7 \pm 10.78 \mathrm{~g}$ $(\mathrm{Cv}=9.17 \%)$, the age of reaching a live weight of $100 \mathrm{~kg}$ $177.3 \pm 0.78$ days $(\mathrm{Cv}=2.98 \%)$, fat thickness at the level of $6-7$ thoracic vertebrae $-20.7 \pm 0.32 \mathrm{~mm}(\mathrm{Cv}=10.36 \%)$, length of chilled carcass $-96.5 \pm 0.31 \mathrm{~cm}(\mathrm{Cv}=1.71 \%)$, length of bacon half of the cooled carcass $-85.5 \pm 0.58 \mathrm{~cm}(\mathrm{Cv}=3.54 \%)$. The complex index of fattening and meat qualities ranges from 126.13 to 182.36 points.

The results of studies of biochemical parameters of blood serum, fattening and meat qualities of young pigs of different intrabreeding differentiation according to the $B$. Tailer index showed that the maximum productivity was characterized by young pigs, in which the complex index ranged from 157.68 to 182.36 points (Table 2).

Thus, animals of group I predominated class II peers at 
the age of reaching a live weight of $100 \mathrm{~kg}$ for 13.3 days $(\mathrm{td}=8.29, P<0.001)$, the average daily increase in live weight during the period of control fattening - $103.0 \mathrm{~g}(\mathrm{td}=2.44$, $P<0.05)$, fat thickness at the level of 6-7 thoracic vertebrae -
$4.6 \mathrm{~mm}(\mathrm{td}=6.67, P<0.001)$, length of chilled carcass $-2.2 \mathrm{~cm}$ $(\mathrm{td}=4.58, \mathrm{P}<0.001)$, the length of the bacon half of the chilled carcass $-3.0 \mathrm{~cm}(\mathrm{td}=2.77, P<0.01)$, the complex index of fattening and meat qualities -28.88 points $(t d=10.61, P<0.001)$.

Table 2

Biochemical parameters of blood serum, fattening and meat qualities of young pigs of different intrabreed differentiation according to the B. Tailer index

\begin{tabular}{|c|c|c|c|}
\hline \multirow{5}{*}{$\begin{array}{l}\text { Indicator, units of meas ureme } \\
\text { nt }\end{array}$} & \multirow{5}{*}{$\begin{array}{l}\text { Biometrycs } \\
\text { indicator }\end{array}$} & \multicolumn{2}{|c|}{ B. Tailer index } \\
\hline & & \multicolumn{2}{|c|}{$\lim$} \\
\hline & & $157.68-182.36$ & $126.13-141.33$ \\
\hline & & \multicolumn{2}{|c|}{ groupe } \\
\hline & & 1 & II \\
\hline \multicolumn{4}{|c|}{ biochemical parameters of blood serum } \\
\hline \multirow{4}{*}{ Urea content, mmol/l } & $\mathrm{n}$ & 3 & 6 \\
\hline & $\overline{\mathrm{X}} \pm S \bar{x}$ & $5.50 \pm 0.378$ & $5.05 \pm 0.385$ \\
\hline & $\sigma \pm S_{\sigma}$ & $0.65 \pm 0.266$ & $0.94 \pm 0.271$ \\
\hline & $\mathrm{C}_{\mathrm{v}} \pm \mathrm{S}_{\mathrm{Cv}}, \%$ & $11.81 \pm 4.840$ & $18.61 \pm 5.378$ \\
\hline \multirow{3}{*}{$\begin{array}{l}\text { Aspartate aminotransferase (AsAT) activity, } \\
\text { units/l }\end{array}$} & $\overline{\mathrm{X}} \pm S \bar{x}$ & $57.3 \pm 9.261$ & $73.5 \pm 8.069$ \\
\hline & $\sigma \pm S_{\sigma}$ & $16.04 \pm 6.573$ & $19.76 \pm 5.710$ \\
\hline & $\mathrm{C}_{\mathrm{v}} \pm \mathrm{S}_{\mathrm{Cv}}, \%$ & $27.97 \pm 11.463$ & $26.89 \pm 7.771$ \\
\hline \multirow{3}{*}{$\begin{array}{c}\text { Alanine aminotransferase (AIAT) activity, } \\
\text { units/l }\end{array}$} & $\overline{\mathrm{X}} \pm S \bar{x}$ & $42.33 \pm 7.125$ & $45.16 \pm 3.745$ \\
\hline & $\sigma \pm S_{\sigma}$ & $12.34 \pm 5.057$ & $9.17 \pm 2.650$ \\
\hline & $\mathrm{C}_{\mathrm{v}} \pm \mathrm{S}_{\mathrm{cv}}, \%$ & $29.15 \pm 11.946$ & $20.31 \pm 5.869$ \\
\hline \multicolumn{4}{|c|}{ fattening and meat qualities } \\
\hline \multirow{4}{*}{$\begin{array}{l}\text { Average daily gain of live weight during the } \\
\text { period of control fattening, } g\end{array}$} & $\mathrm{n}$ & 1 & II \\
\hline & $\overline{\mathrm{X}} \pm S \bar{x}$ & $844.3 \pm 36.11$ & $741.3 \pm 21.96$ \\
\hline & $\sigma \pm S_{\sigma}$ & $29.77 \pm 6.659$ & $17.32 \pm 3.874$ \\
\hline & $\mathrm{C}_{\mathrm{v}} \pm \mathrm{S}_{\mathrm{cv},} \%$ & $3.52 \pm 0.787$ & $2.33 \pm 0.521$ \\
\hline \multirow{3}{*}{ Age of reaching live weight $100 \mathrm{~kg}$, days } & $\overline{\mathrm{X}} \pm S \bar{x}$ & $168.7 \pm 1.17$ & $182.0 \pm 1.10$ \\
\hline & $\sigma \pm S_{\sigma}$ & $3.89 \pm 0.870$ & $3.81 \pm 0.852$ \\
\hline & $\mathrm{C}_{\mathrm{v}} \pm \mathrm{S}_{\mathrm{cv},} \%$ & $2.30 \pm 0.514$ & $2.09 \pm 0.467$ \\
\hline \multirow{3}{*}{$\begin{array}{c}\text { The thickness of the fat at the level of 6-7 } \\
\text { thoracic vertebrae, } \mathrm{mm}\end{array}$} & $\overline{\mathrm{X}} \pm S \bar{x}$ & $18.3 \pm 0.63$ & $22.9 \pm 0.31$ \\
\hline & $\sigma \pm S_{\sigma}$ & $2.11 \pm 0.472$ & $1.08 \pm 0.241$ \\
\hline & $\mathrm{C}_{\mathrm{v}} \pm \mathrm{S}_{\mathrm{Cv}}, \%$ & $11.53 \pm 2.579$ & $4.71 \pm 1.053$ \\
\hline \multirow{3}{*}{ The length of the cooled carcass, $\mathrm{cm}$} & $\overline{\mathrm{X}} \pm S \bar{x}$ & $97.7 \pm 0.25$ & $95.5 \pm 0.42$ \\
\hline & $\sigma \pm S_{\sigma}$ & $0.50 \pm 0.111$ & $1.04 \pm 0.232$ \\
\hline & $\mathrm{C}_{\mathrm{v}} \pm \mathrm{S}_{\mathrm{cv}}, \%$ & $0,51 \pm 0.114$ & $1.08 \pm 0.241$ \\
\hline \multirow{3}{*}{ Length of bacon half of chilled carcass, $\mathrm{cm}$} & $\overline{\mathrm{X}} \pm S \bar{x}$ & $87.0 \pm 0.81$ & $84.0 \pm 0.73$ \\
\hline & $\sigma \pm S_{\sigma}$ & $1.63 \pm 0.364$ & $1.78 \pm 0.398$ \\
\hline & $\mathrm{C}_{\mathrm{v}} \pm \mathrm{S}_{\mathrm{cv}}, \%$ & $1.87 \pm 0.418$ & $2.11 \pm 0.472$ \\
\hline \multirow{3}{*}{$\begin{array}{l}\text { Comprehensive index of fattening and meat } \\
\text { qualities (B. Tailer index), score }\end{array}$} & $\overline{\mathrm{X}} \pm S \bar{x}$ & $164.20 \pm 2.186$ & $135.32 \pm 1.645$ \\
\hline & $\sigma \pm S_{\sigma}$ & $7.25 \pm 1.621$ & $5.70 \pm 1.275$ \\
\hline & $\mathrm{C}_{\mathrm{v}} \pm \mathrm{S}_{\mathrm{Cv}}, \%$ & $4.41 \pm 0.986$ & $4.21 \pm 0.941$ \\
\hline
\end{tabular}

The difference between the animals of these groups in the urea content is equal to $0.45 \mathrm{mmol} / /(\mathrm{td}=0.84, P>0.05)$, the activity of aspartate aminotransferase (AsAT) - 16.2 units/l $(\mathrm{td}=1.31, \mathrm{P}>0.05)$, alanine aminotransferase (AIAT) activity $2.83 \mathrm{u} / \mathrm{l}(\mathrm{td}=0.35, \mathrm{P}>0.05)$.

The coefficient of variation of biochemical parameters of blood serum, fattening and meat qualities of young pigs of the experimental groups ranges from 0.51 to $29.15 \%$.

The results of calculating the coefficients of pairwise correlation between the biochemical parameters of blood serum, fattening and meat qualities of young pigs of the experimental group are shown in table 3 .

This biometric indicator ranges from $-0.637 \pm 0.1682$ (alanine aminotransferase (AsAT) activity $\times$ average daily live weight gain during the control fattening period) to $+0.736 \pm 0.1477$ (alanine aminotransferase (AIAT) activity $\times$ age of $100 \mathrm{~kg}$ live weight). Significant correlations were also established between the following pairs of traits: urea content $x$ length of chilled carcass $\left(+0.394 \pm 0.1408, t_{r}=2.80\right)$ and urea content $x$ length of bacon half of chilled carcass $\left(+0.589 \pm 0.1088, t_{r}=5.41\right)$.

The results of the calculation of the economic efficiency of the use of young pigs of different intra-breed differentiation according to the complex index of fattening and meat qualities (B. Tailer index) are given in Table 4.

It was found that the maximum increase in additional products on the indicator "average daily gain of live weight during the period of control fattening, $g$ " was obtained from animals of group I $-+6.58 \%$. The cost of additional products obtained from young pigs of this group is $+1733.4 \mathrm{UAH}$, provided that the selling price of young pigs to processing enterprises in the region at the time of the study was $44.5 \mathrm{UAH} / \mathrm{kg}$. 
Table 3

Pairwise correlation coefficient between serum biochemical parameters, fattening and meat qualities of young pigs of the experimental group

\begin{tabular}{|c|c|c|c|c|}
\hline \multicolumn{2}{|l|}{ Signs } & \multicolumn{2}{|c|}{ Biometrics indicators } & \multirow{2}{*}{$\begin{array}{l}\text { The strength of the Cheddock } \\
\text { correlation }\end{array}$} \\
\hline$x$ & $y$ & $\mathrm{r} \pm \mathrm{Sr}$ & $\operatorname{tr}$ & \\
\hline \multirow{5}{*}{ Urea content, mmol / I n } & 1 & $+0.266 \pm 0.1549$ & 1.72 & weak \\
\hline & 2 & $-0.161 \pm 0.1623$ & 0.99 & weak \\
\hline & 3 & $-0.191 \pm 0.1606$ & 1.19 & weak \\
\hline & 4 & $+0.394 \pm 0.1408^{* *}$ & 2.80 & moderate \\
\hline & 5 & $+0.589 \pm 0.1088^{* \star *}$ & 5.41 & noticeable \\
\hline \multirow{5}{*}{$\begin{array}{l}\text { Aspartate aminotransferase (AsAT) } \\
\text { activity, units/l }\end{array}$} & 1 & $-0.637 \pm 0.1682^{* *}$ & 3.79 & noticeable \\
\hline & 2 & $+0.736 \pm 0.1477^{* * *}$ & 4.98 & high \\
\hline & 3 & $+0,338 \pm 0.2054$ & 1.65 & moderate \\
\hline & 4 & $-0.033 \pm 0.2181$ & 0.15 & - \\
\hline & 5 & $-0.217 \pm 0.2130$ & 1.02 & weak \\
\hline \multirow{5}{*}{$\begin{array}{l}\text { Alanine aminotransferase (AIAT) activity, } \\
\text { units/l }\end{array}$} & 1 & $-0,278 \pm 0.2096$ & 1.33 & weak \\
\hline & 2 & $+0.141 \pm 0.2160$ & 0.65 & weak \\
\hline & 3 & $+0.162 \pm 0.2153$ & 0.75 & weak \\
\hline & 4 & $+0.110 \pm 0.2169$ & 0.51 & weak \\
\hline & 5 & $+0.333 \pm 0.2058$ & 1.62 & moderate \\
\hline
\end{tabular}

Note: 1 - average daily gain of live weight during the period of control fattening, $\mathrm{g} ; 2$ - age of achievement of live weight of $100 \mathrm{~kg}$, days; 3 - fat thickness at the level of 6-7 thoracic vertebrae, $\mathrm{mm} ; 4$ - length of chilled carcass, $\mathrm{cm} ; 5$ - length of bacon half of chilled carcass, $\mathrm{cm},{ }^{* *}-P<0.01 ;{ }^{* * *}-P<0.001$

Table 4

Economic efficiency of research results

\begin{tabular}{|c|c|c|c|c|c|}
\hline Group & $\mathbf{n}$ & $\begin{array}{c}\text { Gradations of } \\
\text { B. Tailer's index }\end{array}$ & $\begin{array}{c}\text { Average daily gain of live weight for the } \\
\text { period of control fattening, } \mathbf{g}\end{array}$ & $\begin{array}{c}\text { Allowance products, } \\
\%\end{array}$ & $\begin{array}{c}\text { Cost of additional } \\
\text { products, } \mathbf{U A H} / \text { head }^{*}\end{array}$ \\
\hline General sample & 23 & $126.13-182.36$ & $788.7 \pm 10.78$ & - & - \\
\hline II & 12 & $126.13-141.33$ & $741.3 \pm 21.96$ & -6.00 & -1579.37 \\
\hline I & 11 & $157.68-182.36$ & $844.3 \pm 36.11$ & +6.58 & +1733.40 \\
\hline
\end{tabular}

Note: * the selling price of young pigs on the date of the research was UAH 44.5. per $1 \mathrm{~kg}$ of live weight

\section{Conclusions}

1. It was found that the biochemical parameters of blood serum (urea content, mmol / I, aspartate aminotransferase activity (AsAT), units / I, alanine aminotransferase activity (AIAT), units/l) correspond to the physiological norm of clinically healthy young pigs at 150 days of age.

2. Young pigs of large white breed of the controlled herd at the age of reaching live weight of $100 \mathrm{~kg}$ (days), fat thickness at the level of 6-7 thoracic vertebrae $(\mathrm{mm})$, length of chilled carcass $(\mathrm{cm})$ corresponds to class I and elite class.

3. Maximum indicators "average daily gain of live weight during the period of control fattening, kg", "length of chilled carcass, cm", "length of bacon half of chilled carcass, $\mathrm{cm}$ " and minimum values"age of live weight $100 \mathrm{~kg}$, days" and "thickness fat at the level of 6-7 thoracic vertebrae, $\mathrm{mm}$ "are characterized by animals in which the complex index of fattening and meat qualities (B. Tyler's index) ranges from 157.68 to 182.36 points.

4. The number of reliable connections between the biochemical parameters of blood serum, fattening and meat qualities of young pigs of large white breed is equal to $26.67 \%$.

5 . The cost of additional products obtained from young pigs with a $\mathrm{B}$. Tyler index of 157.68 - 182.36 points is equal to +1733.40 UAH/head.

\section{References:}

1. Oliynichenko Ye.K. 2019. Rozroblennya henetychnykh markeriv produktyvnykh oznak svyney na osnovi odnonukleotydnykh polimorfizmiv heniv leptynu ta katepsynu F: avtoref. dys. na zdobuttya nauk. stupenya kand. s.-h. nauk: spets. 06.02.01 «Rozvedennya ta selektsiya tvaryn». [Development of genetic brands of heads of productive traits of pigs on the basis of single nucleotide polymorphisms of leptin and cathepsin F genes] Poltava, $22 \mathrm{p}$.

2. Krasnoshchok O.O. 2020. Formuvannya produktyvnosti sviney u zalezhnosti vid metodiv rozvytku ta intensyvnosti rostu: avtoref. dys. na zdobuttya nauk. stupenya kand. s.-h. nauk: spets. 06.02.01 «Rozvedennya ta selektsiya tvaryn». [Formation of productivity of pigs depending on methods of development and intensity of growth] Poltava, $23 \mathrm{p}$.

3. Bazhov G.M., Komlatskiy V.I. 1989. Biotekhnologiya intensivnogo svinovodstva. [Biotechnology of intensive pig breeding]. Moskva: Rosagropromizdat, 269 p.

4. Bazhov G. M., Stepanova O. V., Kryshtop Ye. A. 2012. Vzaimosvyaz' produktivnykh kachestv sviney s pokazatelyami funktsional'noy aktivnosti vazhneyshikh sistem organizma. [The relationship of the productive qualities of pigs with indicators of the functional activity of the most important systems of the body] Nauchnyy zhurnal KubGAU. № 77 (03). http://ej.kubagro.ru/2012/03/pdf/61.pdf.

5. Inter'yer sil's'kohospodars'kykh tvaryn. 2009. [Interior of farm animals] J.Z. Siratsky and others. Kyiv: Vycsha shkola, 280 p.

6. Lazarev V.M. Vzaimosvyaz' belkov krovi s produktivnymi kachestvami zhivotnykh. Sovremennyye plemennyye i produktivnyye kachestva zhivotnykh. 1992. [The relationship of blood proteins with the productive qualities of animals]. Saratov: Saratovskiy s-.kh. in-t, pp. 66-74. 
7. Lykhach V. Ya. 2005. Hematolohichni pokaznyky svyney riznikh henotipiv. [Hematological parameters of pigs of different genotypes]. Ahrarnyy visnyk Prychornomor'ya, issue 31, pp. 91-92.

8. Negreeva A., Babushkin V. 2004. Dinamika biokhimicheskikh pokazateley krovi molodnyaka sviney pri skreshchivanii [Dynamics of biochemical parameters of the blood of young pigs when crossing]. Svynovodstvo, No. 6. pp. 3-7.

9. Khalak V. I. 2014. Fermenty syrovatky krovi molodnyaku svyney ta yikh zv'yazok z yakisnymy pokaznykamy svynyny.: [Enzymes of blood serum of young pigs and their relationship with quality indicators of pork] Stratehichni napryamky staloho vyrobnytstva silskohospodarskoyi produktsiyi na suchasnomu etapi rozvytku ahrarnoho kompleksu Ukrayiny tezy Vseukrayinskoyi nauk.-prakt. konf. molodykh vchenykh i spetsialistiv (m. Dnipropetrovsk, 22-23 travnya 2014 r.). Dnipropetrovsk: Aktsent, pp. 83-86.

10. Khalak V., Gutyj B., Bordun O., Ilchenko M., Horchanok A. Effect of blood serum enzymes on meat qualities of piglet productivity. Ukrainian Journal of Ecology. 2020. № 10 (1). P. 158-161. (doi: 10.15421/2020_25).

11. Khalak, V., Horchanok, A., Kuzmenko, O., Lytvyshchenko, L., Lieshchova, M., Kalinichenko, A., Liskovich, V., Zagoruy, L. Protein metabolism, physicochemical properties and chemical composition of muscle tissue in Large White weaners. Ukrainian Journal of Ecology, (2020), 10(4), 127-131. doi: 10.15421/2020_ 179.

12. Furata S., Hashimoto T. Partification and properties of 3 - hydroxyacyl coenzyme a dehydrohenese - binding protein from rat liver mitochondria. L. Of biochemistry. 1995. T. 118. № 4. pp. 810-818.

13. Berezovskyy M. D., Khatko I. V. 2005. Metodyky otsinky knuriv i svynomatok za yakistyu potomstva v umovakh pleminnykh zavodiv i pleminnykh reproduktoriv.[Methods for assessing boars and sows on the quality of offspring in breeding plants and breeding breeders] Suchasni metodyky doslidzhen u svynarstvi. Poltava, pp. 32-37.

14. Vashchenko P.A. 2019. Prohnozuvannya pleminnoyi tsinnosti svyney na osnovi liniynykh modeley selektsiynykh indeksiv ta DNK-markeriv [Prediction of breeding value of pigs on the basis of linear models of selection indices and DNA markers]: avtoref. dys. na zdobuttya nauk. stupenya d-ra s.-h. nauk : spets. 06.02 .01 «Rozvedennya ta selektsiya tvaryn». Mykolaiv, 43 p.

15. Laboratorni metody doslidzhen u biolohiyi, tvarynnytstvi ta veterynarniy medytsyni [Laboratory research methods in biology, animal husbandry and veterinary medicine]: dovidnyk / V. V. Vlizlo ta in.; za red. V. V. Vlizlo. Lviv: SPOLOM, 2012. 767 p.

16. Metodika opredeleniya ekonomicheskoy effektivnosti ispol'zovaniya $v$ sel'skom khozyaystve rezul'tatov nauchnoissledovatel'skikh rabot, novoy tekhnologii, izobreteniy i ratsionalizatorskikh predlozheniy.1983. [Methodology for determining the economic efficiency of the use in agriculture of the results of scientific research, new technology, inventions and rationalization proposals] Moskva: VAllPI, $149 \mathrm{p}$.

17. Praktikum po teorii statistiki: uchebnoye posobiye 2003. [Workshop on the theory of statistics] / A. V. Sidorova i dr. Donetsk: Don. nats. un-tet., $252 \mathrm{p}$.

18. Lakin G.F. 1990. Biometriya [Biometrics]. Moskva, 352 p.

\section{Список використаної літератури:}

1. Олійніченко $€$. К. Розроблення генетичних маркерів продуктивних ознак свиней на основі однонуклеотидних поліморфізмів генів лептину та катепсину F: автореф. дис.. на здобуття наук. ступеня канд. с.-г. наук : спец. 06.02 .01 «Розведення та селекція тварин». Полтава, 2019. 22 с.

2. Краснощок О. О. Формування продуктивності свиней в залежності від методів розведення та інтенсивності росту: автореф. дис.. на здобуття наук. ступеня канд. с.-г. наук : спец. 06.02 .01 «Розведення та селекція тварин». Полтава, 2020. $23 \mathrm{c}$.

3. Бажов Г. М., Комлацкий В. И. Биотехнология интенсивного свиноводства. Москва: Росагропромиздат, 1989. 269 с.

4. Бажов Г. М., Степанова О. В., Крыштоп Е. А. Взаимосвязь продуктивных качеств свиней с показателями функциональной активности важнейших систем организма. Научный журнал КубГАУ. $2012 . \quad$ № 77 (03). http://ei.kubagro.ru/2012/03/pdf/61.pdf.

5. Інтер'єр сільськогосподарських тварин / Й. 3. Сірацький та ін. Київ: Вища освіта, 2009. 280 с.

6. Лазарев В. М. Взаимосвязь белков крови с продуктивными качествами животных. Современные племенные и продуктивные качества животных. Саратов: Саратовский с-.х. ин-т, 1992. С. 66-74.

7. Лихач В. Я. Гематологічні показники свиней різних генотипів. Аграрний вісник Причорномор'я. 2005. Вип. 31. С. $91-92$.

8. Негреева А., Бабушкин В. Динамика биохимических показателей крови молодняка свиней при скрещивании. Свиноводство. 2004. № 6. С. 3-7.

9. Халак В. І. Ферменти сироватки крові молодняку свиней та їх зв'язок з якісними показниками свинини. Стратегічні напрямки сталого виробництва сільськогосподарської продукції на сучасному emani розвитку аграрного комплексу України: тези Всеукраїнської наук.-практ. конф. молодих вчених і спеціалістів (м. Дніпропетровськ, 22-23 травня 2014 р.). Дніпропетровськ: Акцент ПП, 2014. С. 83-86.

10. Khalak V., Gutyj B., Bordun O., Ilchenko M., Horchanok A. Effect of blood serum enzymes on meat qualities of piglet productivity. Ukrainian Journal of Ecology. 2020. № 10 (1). P. 158-161. (doi: 10.15421/2020_25).

11. Khalak, V., Horchanok, A., Kuzmenko, O., Lytvyshchenko, L., Lieshchova, M., Kalinichenko, A., Liskovich, V., Zagoruy, L. Protein metabolism, physicochemical properties and chemical composition of muscle tissue in Large White weaners. Ukrainian Journal of Ecology, (2020), 10(4), 127-131. doi: 10.15421/2020_179.

12. Furata S., Hashimoto T. Partification and properties of 3 - hydroxyacyl coenzyme a dehydrohenese - binding protein from rat liver mitochondria. L. Of biochemistry. 1995. T. 118. № 4. P. 810-818.

13. Березовський М. Д., Хатько І. В. Методики оцінки кнурів і свиноматок за якістю потомства в умовах племінних за- 
водів і племінних репродукторів. Сучасні методики досліджень у свинарстві. Полтава, 2005. С. 32-37.

14. Ващенко П. А. Прогнозування племінної цінності свиней на основі лінійних моделей селекційних індексів та ДНКмаркерів: автореф. дис.. на здобуття наук. ступеня д-ра с.-г. наук : спец. 06.02.01 «Розведення та селекція тварин». Миколаїв, 2019. 43 c.

15. Лабораторні методи досліджень у біології, тваринництві та ветеринарній медицині: довідник / В. В. Влізло та ін.; за ред. В. В. Влізло. Львів: СПОЛОМ, 2012. 767 с.

16. Методика определения экономической эффективности использования в сельском хозяйстве результатов научноисследовательских работ, новой технологии, изобретений и рационализаторских предложений. Москва: ВАИИПИ, 1983. 149 c.

17. Практикум по теории статистики: учебное пособие / А. В. Сидорова и др. Донецк: Дон. нац. ун-тет., 2003. 252 с. 18. Лакин Г. Ф. Биометрия. Москва, 1990. 352 с.

Халак Віктор Іванович, кандидат сільськогосподарських наук, ст. науковий співробітник, завідувач лабораторією тваринництва, Державна установа «lнститут зернових культур НААН України» (Дніпро, Україна)

Ознаки продуктивності молодняку свиней великої білої породи та їх зв'язок з вмістом сечовини та активністю деяких ферментів сироватки крові

Наведено результати досліджень відгодівельних та м'ясних якостей молодняку свиней великої білої породи, деяких біохімічних показників сироватки крові (вміст сечовини, активність аспартатамінотрансферази (AcAT), активність аланінамінотрансферази (АлАТ), а також розраховано економічну ефективність результатів досліджень. Дослідження проведено в СТОВ «Дружба - Казначеївка» Дніпропетровської області, у Науково-дослідному центрі біобезпеки та екологічного контролю ресурсів АПК Дніпропетровського державного аграрно-економічного університету, м'ясокомбінаті «Джаз» та лабораторії тваринниитва Державної установи Інститут зернових культур НААН України. Робота виконана згідно програми наукових досліджень НААН України №30 «Інноваційні технології племінного, промислового та органічного виробництва продукції свинарства» («Свинарство»), номер державної реєстрації 0116U001247. Об'єктом дослідження був молодняк свиней великої білої породи. Оцінку тварин за відгодівельними і м'ясними якостями проводили з урахуванням наступних показників: середньодобовий приріст живої маси за період контрольної відгодівлі, г, вік досягнення живої маси 100 ке, діб, товщина шпику на рівні 6-7 грудних хребців, мм, довжина охолодженої туші, см, довжина беконної половини охолодженої півтуші, см (М. Д. Березовський, І. В. Хатько, 2005). Комплексну оцінку молодняку свиней за відгодівельними і м'ясними якостями розраховували за індексом Б. Тайлера (П. А. Ващенко, 2019), біометричні показники - за методиками Г. Ф. Лакіна (1990). Економічну ефективність результатів досліджень розраховували за загальноприйнятою методикою (Методика определения экономической ..., 1983). Встановлено, що вміст сечовини, активність аспартатамінотрансфрерази (АсAT) та аланінамінотрансфрерази (АлАТ) у сироватці крові молодняку свиней піддослідної групи відповідає фізіоло-

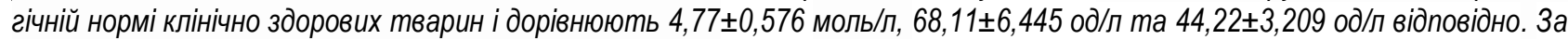
віком досягнення живої маси 100 ке (діб), товщиною шпику на рівні 6-7 грудних хребців (мм) та довжиною охолодженої туші (см) тварини зазначеної виробничої групи та породи відповідають I класу та класу «еліта». Максимальними показниками «середньодобовий приріст живої маси за період контрольної відгодівлі, кट», «довжина охолодженої туші, см», «довжина беконної половини охолодженої туші, см» та мінімальними значеннями «вік досягнення живої маси 100 кट, днів» $i$ «товщина шпику на рівні 6-7 грудних хребців, мм» характеризуються тварини, у яких комплексний індекс відгодівельних та м'ясних якостей (індекс Б. Тайлера) коливається у межах від 157,68 до 182,36 балів. Кількість достовірних зв'язків між біохімічними показниками сироватки крові, відгодівельними та м'ясними якостями молодняку свиней великої білої породи дорівнює 26,67 \%. Вартість додаткової продукції, яку одержують від молодняку свиней з індексом Б. Тайлера 157,68 182,36 балів дорівнює $+1732,04$ грн./гол.

Ключові слова: молодняк свиней, біохімічні показники сироватки крові, відгодівельні та м'ясні якості, комплексна оцінка, індекс, мінливість, кореляція, економічна ефективність

Дата надходження до редакції: 15. 05.2021 р. 